\title{
Uzaktan eğitim yoluyla yürütülen Türk dili derslerinin değerlendirilmesi: nitel bir araştırma
}

\section{Ömer ÖZER' \\ Yunus Emre ÇEKİĊं 2}

\begin{abstract}
APA: Özer, Ö.; Çekici, Y. E. (2020). Uzaktan eğitim yoluyla yürütülen Türk dili derslerinin değerlendirilmesi: nitel bir araştırma. RumeliDE Dil ve Edebiyat Araştırmaları Dergisi, (Ö7), 92110. DOI: $10.29000 /$ rumelide.808251.
\end{abstract}

\section{$\ddot{\mathbf{O} z}$}

Bu çalışma, Adana Alparslan Türkeş Bilim ve Teknoloji Üniversitesinin çeşitli bölümlerinde lisans öğrenimi gören ve ortak zorunlu Türk Dili dersini alan ya da daha önceden almış olan Türk ve yabancı uyruklu öğrenciler ve bu dersi yürüten öğretim elemanlarıyla gerçekleştirilmiş olan yarı yapılandırılmış görüşmeleri ele almaktadır. Nitel araştırma tasarımına sahip olan bu çalışma öğretim görevlileri, Türk ve yabancı uyruklu öğrencilerin görüşleri üzerinden uzaktan eğitim sisteminin işleyişini incelemektedir. Araştırma temelde ders içeriği, tutumlar, teknik yönler, dil becerilerinin gelişimi ve öğretim yöntemleri üzerinden sürecin farklı paydaşların görüşlerindeki benzer ve farklı başlıkları bulmayı amaçlamıştır. İlgili üniversitede 2019-2020 eğitim öğretim döneminde öğrenim gören 25 Türk, 5 yabancı uyruklu öğrenci ile bu dersi yürüten 4 öğretim görevlisi, bu araştırmanın çalışma grubunu oluşturmaktadır. Çalışma grubunun belirlenmesinde ölçüt örnekleme kullanılmıştır. Katılımcılara amaç, başarı, dil becerilerinin gelişimi, içerik bağlamında uzaktan eğitim deneyimlerinin nasıl geçtiği sorulmuştur. Yapılan çözümlemeler sonucunda hem Türk hem de yabancı uyruklu öğrencilerin derslere devam ve çevrim içi etkin katılım konusunda motivasyon eksikliği yaşadıkları bulunmuştur. Öğrenciler alanlarına özgü aldıkları bölüm dersleriyle kıyasladıkları zaman Türk dili dersine çalışma anlamında öncelik vermediklerini ve çoğunlukla ilgisiz davrandıklarını ifade etmişlerdir. Buna karşın yerleşke dışından derslere katılabilmeleri ve zaman yönetimi açısından uzaktan eğitim sistemini fiziksel dersliklerde aldıkları derslere yeğlediklerini söylemişlerdir. Öte yandan öğretim niteliği açısından ise örgün eğitimi uzaktan eğitime tercih ettiklerini belirtmişlerdir. Yabancı uyruklu öğrenciler, hazırbulunuşluklarının bu dersi almak için yeterli olmadığını ifade ederken öğretim elemanları uzaktan eğitim sisteminin öğrencilerin anlatma becerilerinin gelişimine olumlu etki etmediğini vurgulamıştır.

Anahtar kelimeler: Uzaktan öğretim, lisans öğrencileri, yabancı uyruklu öğrenciler, öğretim görevlileri, temel dil becerileri, Türkçe eğitimi

$1 \quad$ Dr. Öğr. Üyesi, Adana Alparslan Türkeş Bilim ve Teknoloji Üniversitesi, İnsan ve Toplum Bilimleri Fakültesi, MütercimTercümanlık Bölümü (Adana, Türkiye), oozer@atu.edu.tr, ORCID ID: oooo-ooo1-8502-3145 [Makale kayıt tarihi: 24.08.2020-kabul tarihi: 20.10.2020; DOI: 10.2900o/rumelide.808251]

2 Öğr. Gör., Adana Alparslan Türkeş Bilim ve Teknoloji Üniversitesi, Rektörlük Türk Dili Bölümü (Adana, Türkiye), yecekici@atu.edu.tr, ORCID ID: 00oo-0oo3-0247-3779 


\title{
Evaluation of Turkish language courses in distance education: A qualitative research
}

\begin{abstract}
This article reports a small-scale study involving semi-structured interviews with students who were taking or had taken a compulsory Turkish language course on a distance-learning module at a state university in the south of Turkey. This qualitative research study was designed to investigate the implementation of the online learning system used in Turkish language courses by exploring it from the perspectives of instructors, domestic students, and international students. The study examined course content, attitude, technical problems, and pedagogical approaches as identified by the participants. Semi-structured interviews were conducted with 25 domestic students, five international students, and four instructors. The interview questions were broadly based around what the students had experienced throughout the course delivered by distance education and the extent to which the distance-education method had helped them to develop their macro language skills. The researchers also asked the participants' opinions about whether there was anything else that the university or their instructor could have done to teach the content more effectively. The students identified the challenges which they had experienced as a lack of motivation to attend the course and considering the course as inferior to their departmental courses. They also identified time management and ubiquitous learning as their main motivation for the distance-learning classes. The findings showed that the participants had contradictory views about the delivery of the course and even about the existence of such a course.
\end{abstract}

Keywords: Distance education, undergraduate students, international students, instructors, macro language skills, Turkish education

\section{Giriş}

Teknolojinin gelişmesi, yaşam koşullarını değiştirdiği gibi öğrenme araçlarının da farklılaşmasını beraberinde getirmiştir. Teknolojiyle değişen yaşam yeni gereksinimleri ortaya çıkarmış, bu süreçte de örgün eğitime alternatif olarak uzaktan öğretim kavramı doğmuştur. Aynı mekânda bulunmayan öğrenci, öğretmen ve eğitim materyallerinin iletişim teknolojileri aracılığıyla bir araya getirildiği bir eğitim öğretim etkinliği olan uzaktan eğitim (Kılınç, 2015, s. 10), günümüzde özellikle yükseköğretim kademesinde sıkça tercih edilmektedir. Dünyanın pek çok yerinde olduğu gibi Türk yükseköğretiminde de uzaktan eğitim, son yıllarda yaygınlık kazanmıştır (Bozkurt, 2017; Çakır vd., 2015; Yaman, 2015).

Uzaktan eğitimin yükseköğretimde yeğlenmesinin altında yatan çeşitli nedenler bulunmaktadır. Sınıfta farklı seviyelerdeki öğrencilerin öğrenme eksikliklerini kendi ilerleme hızlarında giderebilmelerine olanak sağlayabilecek olması, uzaktan eğitimin üniversitelerde tercih edilmesinin altında yatan başlıca neden olarak düşünülebilir (Gregory ve Lodge, 2015; Subic ve Maconachie, 2004). Buna ek olarak, zaman ve mekân sınırlılı̆̆ını ortadan kaldırması (Croft, Dalton ve Grant, 2010; Subic ve Maconachie, 2004), sosyo-ekonomik statü farklarını gizlemesi (Nage-Sibande ve Morolong, 2018), öğrencilerin bireysel ilerlemelerinin takip edilebilmesi (Croft vd., 2010), mekân maliyetinin yanı sıra öğrenci giderlerini azaltması, ders takibine getirilen esneklik ve dersin görsel-işitsel ögelerle zenginleştirilmesi (Tulunay Ateş, 2014, s. 25) yükseköğretimde uzaktan eğitimin tercih edilmesinin nedenleri arasında sayılabilir. Bu gerekçelerle üniversitelerde, bazı bölümlerde bütün dersler uzaktan eğitim yoluyla verilmeye başlanmıştır (Akdemir, 2011). Bununla beraber bazı bölümlerde örgün 
eğitimin içinde Türk Dili, Atatürk İlkeleri ve İnkılap Tarihi, yabancı dil gibi ortak zorunlu dersler, uzaktan eğitim yoluyla gerçekleştirilmektedir (Bircan, Eleroğlu, Arslan ve Ersoy, 2018; Gürer, Tekinarslan ve Yavuzalp, 2016). Ortak zorunlu dersler arasında yer alan Türk Dili I ve Türk Dili II dersleri, son ylllarda birçok üniversitede uzaktan eğitim yoluyla yürütülmektedir (Gürer vd., 2016). Türk öğrencilerin yanı sıra, Türk yükseköğretimini tercih eden yabancı uyruklu öğrenciler de uzaktan eğitim yoluyla bu dersi almaktadır (Şahin ve Demirtaş, 2014).

Türk Dili dersi, Türkiye'deki üniversitelerde hem ön lisans hem de lisans programlarının birinci sınıfında iki yarıyl şeklinde okutulan ortak ve zorunlu bir derstir. Türk Dili dersi 4/11/1981 tarihli ve 2547 Sayılı Yükseköğretim Kanunu'nun 5/i. maddesine göre yükseköğretim kurumlarında zorunludur ve en az iki yarıyıl okutulmalıdır. YÖK’ün çerçeve programda, bu dersin amacı öğrencilere yazılı ve sözlü olarak Türkçeyi doğru ve güzel kullanabilme yeteneği kazandırmak ve öğrencilerin ana dili bilincini geliştirmek şeklinde ifade edilmiştir (Karataş, 2013, s. 1896). Alanyazınında ayrıca bu dersin temel amacının öğrencilerin anlama (dinleme, okuma) ve anlatma (konuşma, yazma) becerilerini geliştirmek olduğu vurgulanmaktadır (Cemiloğlu, 2004; Sarıtunç, 2016; Akkaya ve Sevindi, 2015). Buradan yola çıarak, günümüzde birçok üniversitede uzaktan eğitim sistemiyle yürütülen Türk Dili dersinin bilgi değil; beceri temelli bir ders olduğunu söylemek olanaklıdır.

Kavcar, Oğuzkan ve Sever (1999), ana dili eğitiminin iki temel boyutu bulunduğunu; dinleme ve okuma becerilerinin anlamayı; konuşma ve yazma becerilerinin de anlatmayı kapsadığını belirtmektedir. Benzer bir biçimde Özdemir (1983) de ana dili derslerinin dört temel amacı olduğunu vurgulamaktadır. Buna göre okuduğunu eksiksizce anlama; düşüncelerini, duygu, izlenim ve tasarılarını belirli bir amaç doğrultusunda yazıya dökebilme; konuşmaları dinleyerek iletileri anlama; düşünce, duygu, izlenim ve tasarılarını güzel, doğru ve etkili bir biçimde söze dönüştürme, ana dili eğitiminin temel amacıdır. Üniversitelerde okutulan Türk Dili dersleri de söz konusu hedefleri taşımaktadır. Bununla beraber uzaktan eğitim sistemiyle verilen Türk Dili derslerinin, öğrencilerin dil becerilerinin gelişimine ne ölçüde katkı sunduğu, önemli bir araştırma konusudur.

Alanyazını taramasında, uzaktan eğitim yürütülen Türk Dili derslerine yönelik bazı çalışmalara rastlanmıştır. Arslan (2018) çalışmasında, öğretim elemanlarının, uzaktan eğitimle yürütülen Türk Dili derslerinin öğrencilerin dil becerilerini geliştirmediğini; öğrencilerin de bu derslerin millî benlik oluşturmada yetersiz kaldığını düşündükleri sonucuna ulaşmıştır. Kırbaş (2017), üniversite öğrencilerinin uzaktan eğitimle yürütülen Türk Dili dersine karşı genelde olumsuz tutuma sahip olduğunu belirlemiştir. Kan ve Fidan (2016), uzaktan eğitimle yürütülen Türk Dili dersine yönelik, öğrencilerin derslerin arşivden tekrar izlenmesini olumlu buldukları, bununla beraber pratik ve iletişim eksikliğini bir sorun olarak gördükleri sonucuna ulaşmışlardır.

Alanyazını incelendiğinde uzaktan eğitim yoluyla yürütülen Türk Dili derslerinin öğrencilerin dil becerilerinin gelişimine etki edip etmediğinin kısıtlı sayıdaki birkaç çalışma dışında (Arslan, 2018; Kan ve Fidan, 2016) araştırılmadığı görülmektedir. Ayrıca yabancı uyruklu öğrencilerin, Türk Dili dersinde yaşadıkları sorunları ele alan bir çalışmaya da rastlanmamıştır. Türk Dili derslerinin temel amacının öğrencilerin anlama ve anlatma becerilerini geliştirmek olduğu düşünüldüğünde, uzaktan eğitim sisteminin buna ne kadar elverişli bir araç olduğu hem öğretim elemanı hem de Türk ve yabancı uyruklu öğrencilerin bu konuya ilişkin görüşleri araştırmaya değer bir konu olarak gündeme gelmektedir. Buradan hareketle bu çalışmada, öğretim elemanları ile Türk ve yabancı uyruklu öğrencilerin görüşlerini irdeleyerek uzaktan eğitim yoluyla yürütülen Türk Dili derslerinin temel dil becerilerinin gelişimi üzerinde ne tür bir etkisinin olduğunun belirlenmesi amaçlanmıştır. 


\subsection{Problem durumu}

Türkiye'deki yükseköğretim kurumlarının stratejik planlarında beyan ettikleri uluslararasılaşma çabalarının (Efe ve Ozer, 2015) bir yansıması olarak Türk yükseköğretiminde uluslararası öğrenci hareketliliğine ayrı bir önem verilmektedir (Kethüda, 2015). Üniversitelerin değişim geçirdikleri bir diğer alan ise daha fazla öğrenciyi kabul edebilmek (Croft vd., 2010; Subic ve Maconachie, 2004) ve değişen öğrenci profili ve yükseköğretim kurumları arası rekabete uyum sağlayabilmek adına tercih ettikleri (Akdemir, 2011) internet üzerinden verilen dersler olmuştur. Geçtiğimiz birkaç yl içerisinde yükseköğretimde uygulama esasları açıkça tanımlanan uzaktan eğitim programlarının sayıları, giderek artmaktadır (YÖK, 2018). Uzaktan eğitim programlarında yaşanan bu artışın yanı sıra aynı zamanda yükseköğretimde hem Türk hem de yabancı uyruklu öğrencilerin sayılarında son yıllarda önemli bir artış yaşanmaktadır (Kethüda, 2015). Yabancı uyruklu öğrencilerin artış göstermesi Türkiye'deki yükseköğretim kurumlarının stratejik planlarında beyan ettikleri uluslararasılaşma çabaları ile de yakından ilişkilidir. Ancak nicelik ve nitelik her zaman doğrusal bir ilişki taşımamaktadır. Yükseköğretimdeki arz ve talep ilişkisi sonucunda gerçekleşen hızlı değişim, bu değişimin aksayan yönleri olup olmadığının incelenmesine ve varsa aksayan yönlerinin bulunup ortadan kaldırılmasına yönelik çalışmaları zorunlu kılmaktadır. Alanyazınında Türk yükseköğretiminde uzaktan eğitimi niceliksel bir yaklaşımla ele alan birtakım çalışmalar bulunmakla beraber (Cabı ve Ersoy, 2017; Çakmak, 2013; Kethüda, 2015) bu çalışma, Türk yükseköğretiminde uzaktan eğitim uygulamalarını ortak zorunlu bir ders olan Türk Dili dersleri üzerinden nitel bir yaklaşımla ortaya çıkarmayı amaçlamaktadır. Yükseköğretim kurumları arasında sadece ulusal alanda değil aynı zamanda uluslararası düzlemde rekabetin yoğun yaşandığı bu dönemde, ülkemizin ve kurumlarımızın stratejik planlamalarıyla örtüşecek, niteliği yüksek dersler önem arz etmektedir. Bu doğrultuda, çalışmanın yürütüldüğü üniversiteden alınan örneklemden hareketle uzaktan eğitim uygulamalarını Türk Dili dersleri üzerinden hem öğretim elemanı hem de Türk ve yabancı uyruklu öğrencilerin bakış açılarıyla ayrıntılı bir şekilde incelemek bu araştırmanın öncelikli hedefidir. Alanyazını taraması sonucunda uzaktan eğitimle Türk Dili derslerini alan yabancı uyruklu öğrencilerin görüşlerinin incelendiği bir çalışmaya rastlanmaması ve buna ek olarak sürecin etkin aktörleri olan dersi veren öğretim görevlilerinin de çalışmaya dâhil edilmiş olması bu araştırmayı özgün kılan yönlerdendir. Araştırmanın bir diğer özgün yanı da doğrudan temel dil becerilerinin gelişimine odaklanmasıdır. $\mathrm{Bu}$ çalışmayı alanyazınında rastlanılan çalışmalardan ayıran bir diğer özellik ise ön lisans programına kayıtlı öğrenciler yerine lisans programına kayıtlı birinci sınıftan dördüncü sınıfa kadar üniversite genelinde mevcut altı fakültenin tamamına ait öğrencilerin araştırmaya dâhil edilmiş olmasıdır. $\mathrm{Bu}$ doğrultuda araştırmada yanıtı aranan temel soru şudur: Uzaktan eğitim yoluyla verilen Türk Dili 1 ve 2 dersleri; dersin paydaşlarına göre amaçlar, öğretim niteliği ve temel dil becerilerinin gelişimi açısından nasıl değerlendirilmektedir? Bu soruyu yanıtlayabilmek için uzaktan eğitim yoluyla verilen Türk Dili derslerine ilişkin Türk öğrencilerin, yabancı uyruklu öğrencilerin ve bu dersi yürüten öğretim elemanlarının görüşlerine başvurulmuştur.

\section{Yöntem}

Uzaktan eğitim yoluyla yürütülen Türk Dili derslerinin öğrencilerin temel dil becerilerinin gelişimi üzerindeki etkisini inceleyen bu çalışma, olgubilim desenine sahip nitel bir araştırmadır. Esnek ve bütüncül bir yaklaşımı savunan nitel araştırma yaklaşımında bireylerin görüş, deneyim ve algılarının araştırma sürecine dâhil edilmesi oldukça önemlidir (Yıldırım ve Şimşek, 2013). 
İnsan doğasını ölçmenin kolay olmadığını savunan nitel araştırma yaklaşımında, zaman ve mekân farklılıklarının etkisinden dolayı araştırmada incelenen olguların ve sonuçların genellenebilirliğine mesafeli yaklaşılır (Fraenkel, Wallen \& Hyun, 2012). Benzer bir biçimde, bu araştırmada da odaktaki olguyu ayrıntılı bir şekilde incelemeyi amaçlarken, genelleme yapmaktan kaçınılmıştır. Bu doğrultuda çalışmada, nitel araştırmalarda yaygın kullanılan veri toplama yöntemlerden biri olan yarı yapılandırılmış yüz yüze görüşme yöntemi kullanılmıştır. Yüz yüze görüşme yöntemi, araştırma grubunun görüşlerinin ayrıntılı bir biçimde toplanmasına ve derinlemesine bir değerlendirmeye olanak sağladığı için (Ylldırım ve Şimşek, 2013) bu yöntemin araştırmanın amacına uygun olduğu düşünülmektedir. Yüz yüze görüşme yöntemi, insanları anlamanın; onların gerçeklik algısına, gerçekliği yapılandırmasına vakıf olmanın yollarından biridir (Fraenkel vd., 2012). Bu bağlamda araştırmada, yüz yüze görüşme yöntemi, hem öğretim elemanı hem de öğrencilerin algı ve görüşlerini derinlemesine analiz etmeye olanak tanımaktadır.

\section{1. Çalışma grubu}

Adana Alparslan Türkeş Bilim ve Teknoloji Üniversitesinde 2019-2020 eğitim öğretim yllında öğrenim gören lisans öğrencileri, araştırmanın evrenini oluşturmaktadır. İlgili üniversitede 2019-2020 eğitim öğretim döneminde öğrenim gören 25 Türk, 5 yabancı uyruklu öğrenci ile bu dersi yürüten 4 öğretim görevlisi, bu araştırmanın çalışma grubunu oluşturmaktadır. Çalışma grubunun belirlenmesinde amaçlı örnekleme stratejilerinden ölçüt örnekleme kullanılmıştır ve katılımda gönüllülük esası temel alınmıştır. Araştırmaya sadece uzaktan eğitim ile Türk Dili dersini almakta olan ve daha önceden bu dersi almış olan öğrenciler gönüllülük esasına göre dâhil edilmiştir. Araştırmaya katılacak öğrencilerin belirlenmesinde maksimum çeşitliliği sağlayabilmek için öğrencilerin farklı fakülte ve bölümlerde okuyor olmasına ve mümkün olduğunca cinsiyet dağılımının eşit olmasına dikkat edilmiştir. Çalışma grubunun demografik nitelikleri Tablo 1 ve Tablo 2'de verilmiştir.

Tablo 1. Lisans öğrencileri çalışma grubunun demografik özellikleri

\begin{tabular}{lllll}
\hline Kod & Cinsiyet & Uyruk & Fakülte & Sinıf \\
\hline YÖ1 & Erkek & Suriye & İşletme & 4 \\
YÖ2 & Erkek & Suriye & Siyasal Bilgiler & 1 \\
YÖ3 & Erkek & Azerbaycan & Havacılık ve Uzay Bilimleri & 1 \\
YÖ4 & Erkek & Suriye & Mühendislik & 4 \\
YÖ5 & Erkek & Suriye & Mühendislik & 4 \\
TÖ1 & Kadın & T.C. & İşletme & 4 \\
TÖ2 & Erkek & T.C. & İşletme & 3 \\
TÖ3 & Kadın & T.C. & İşletme & 3 \\
TÖ4 & Erkek & T.C. & İşletme & 2 \\
TÖ5 & Kadın & T.C. & İşletme & 2 \\
TÖ6 & Kadın & T.C. & İşletme & 1 \\
TÖ7 & Erkek & T.C. & İşletme & 1 \\
TÖ8 & Kadın & T.C. & İnsan ve Toplum Bilimleri & 4 \\
TÖ9 & Erkek & T.C. & İnsan ve Toplum Bilimleri & 4 \\
TÖ10 & Kadın & T.C. & İnsan ve Toplum Bilimleri & 3 \\
TÖ11 & Erkek & T.C. & İnsan ve Toplum Bilimleri & 3
\end{tabular}




\begin{tabular}{lllll} 
TÖ12 & Kadın & T.C. & İnsan ve Toplum Bilimleri & 2 \\
TÖ13 & Erkek & T.C. & İnsan ve Toplum Bilimleri & 2 \\
TÖ14 & Kadın & T.C. & İnsan ve Toplum Bilimleri & 1 \\
TÖ15 & Erkek & T.C. & İnsan ve Toplum Bilimleri & 1 \\
TÖ16 & Erkek & T.C. & Siyasal Bilgiler & 2 \\
TÖ17 & Erkek & T.C. & Siyasal Bilgiler & 1 \\
TÖ18 & Erkek & T.C. & Mimarlık ve Tasarım & 2 \\
TÖ19 & Kadın & T.C. & Mimarlık ve Tasarım & 1 \\
TÖ20 & Erkek & T.C. & Havacllı ve Uzay Bilimleri & 1 \\
TÖ21 & Kadın & T.C. & Mühendislik & 4 \\
TÖ22 & Erkek & T.C. & Mühendislik & 3 \\
TÖ23 & Erkek & T.C. & Mühendislik & 2 \\
TÖ24 & Erkek & T.C. & Mühendislik & 1 \\
TÖ25 & Erkek & T.C. & Mühendislik & 1 \\
\hline
\end{tabular}

Tablo 2. Öğretim elemanları çalışma grubunun demografik özellikleri

\begin{tabular}{llll}
\hline Kod & Cinsiyet & Görev Yılı & Mezun Olduğu/Devam Ettiği Doktora Programı \\
\hline ÖE1 & Kadın & 12 & Türk Dili ve Edebiyatı \\
ÖE2 & Erkek & 7 & Yabancı Dil Olarak Türkçe Öğretimi \\
ÖE3 & Erkek & 18 & Yabancı Dil Olarak Türkçe Öğretimi \\
ÖE4 & Kadın & 8 & Yabancı Dil Olarak Türkçe Öğretimi \\
\hline
\end{tabular}

Her ne kadar görüşmeler öncesinde eşit sayıda kadın ve erkek katılımcıya ulaşılmak hedeflense de, evrende daha çok erkek öğrenci yer alması ve görüşmelere katılımdaki gönüllülük esası gereğince uygulama esnasında homojen bir dağılım oluşmamıştır. Tablo 1 ve Tablo 2'ye bakıldığında, çalışmaya katılan öğrencilerin 10'nun kadın 20'sinin erkek olduğu görülmektedir. Öğretim elemanlarında ise katılımcıların cinsiyet olarak eşit bir dağılım gösterdikleri görülmektedir. Öğretim görevlilerinden oluşan katılımcılar incelendiği zaman o ana kadar en az bir yarıyıl uzaktan eğitim ile Türk Dili dersini verdikleri görülmüştür.

\subsection{Verilerin toplanması ve çözümlenmesi}

Verileri toplamak için araştırmacılar tarafından yarı yapılandırılmış görüşme soruları hazırlanmıştır. Görüşme soruları araştırmanın amaçları doğrultusunda araştırmacılar tarafından geliştirilmiştir. Bu esnada, yarı yapılandırılmış görüşme sorularının dil ve anlatım açısından açık ve anlaşılır bir nitelik taşıması için Türkçe Eğitimi alanında görev yapan bir öğretim üyesinin uzman görüşüne başvurulmuş, ardından amaca hizmet edip etmediğini sınamak için araştırmaya katılmayan bir öğretim elemanı ve bir öğrenciyle pilot görüşme yapılmıştır. Böylece yarı yapılandırılmış araştırma sorularına son şekli verilmiştir. Sonrasında, araştırmanın yürütüleceği üniversiteden resmî yazllı izin alınmıştır. Öğretim elemanları ve öğrencilere yöneltilen sorular sözcük seçimleri ve hitap açılarından küçük farklıllıklar gösterse de genel anlamda aşağıdaki gibidir.

- Uzaktan eğitim ile aldığınız Türk Dili dersleri, dinleme, konuşma, okuma ve yazma becerinizin gelişimine nasıl etki etmektedir? Neden? 
- Uzaktan eğitim ile aldığınız Türk Dili derslerinde, temel dil becerilerinizi (dinleme, konuşma, okuma, yazma) geliştirmek için neler yapılabilir?

- Uzaktan eğitim ile aldığınız derslerde aksayan yönler var mıydı? Eğer varsa açıklayınız.

- Uzaktan eğitim ile yürütülen Türk Dili derslerinin Yükseköğretim Kurulunun belirlediği çerçeve programında Türk Dili dersleri için belirtilen hedeflerle ne derece uyuştuğunu düşünüyorsunuz?

Yukarıda yer alan sonuncu soru sadece öğretim elemanlarına yöneltilmiştir. Soruların soruluş sırası büyük oranda korunmakla beraber görüşmenin seyrine göre değişen sıralarda da sorulmuştur. Mevcut çalışmanın araştırmacılardan birinin yabancı dil öğretimi alanında görevli olması görüşmeler yürütülürken katılımcıların daha rahat ve tehdit hissetmeden yanıtlar vermeleri açısından yararlı olmuştur.

Yüz yüze görüşme esnasında veriler, katılımcıların onayları doğrultusunda ses kayıt cihazıyla toplanmıştır. Öğrencilerle yapılan görüşmeler, samimi cevap vermeye daha elverişli olduğu düşüncesiyle onların istekleriyle ofiste ya da üniversite kantininde toplanmıştır. Öğretim elemanlarıyla yapılan görüşmeler ise öğretim elemanlarının ofislerinde gerçekleştirilmiştir. Öğrenciler ile yapılan görüşmeler ortalama 6 dakika sürerken öğretim görevlileri ile yapılan görüşmeler ortalama 10 dakika sürmüştür. Yüz yüze görüşmeyi tercih etmeyen katılımcılar için görüş formları bırakılmış ve katılımcılar kendileri için uygun olan zamanlarda formları yazılı olarak doldurmuşlardır. Yarı yapılandırılmış görüş formu, yarı yapılandırılmış görüşmeler için hazırlanmış olan aynı sorulardan oluşmuştur.

Yüz yüze görüşme ya da görüş formu aracılı̆̆ıyla toplanan veriler, öncelikle yazıya dökülmüş, ardından nitel içerik analizi tekniğiyle analiz edilmiştir. İçerik analizinde temel amaç, toplanan verilerden kavramlara ulaşmak, bu kavramları mantıklı bir biçimde düzenlemek ve ilişkilendirmektir (Yıldırım ve Şimşek, 2013). Bu araştırmanın konusuna ilişkin kavramlara ve ilişkilere ulaşmak amacıyla gerçekleştirilen içerik analizi sonucunda elde edilen nitel veriler önce kodlanmış, sonrasında temalar belirlenmiş, araştırmacıların görüş alışverişleri sonrasında kodlar ve temalar düzenlenmiş ve son olarak da Türk ve yabancı uyruklu öğrencilerle, öğretim elemanlarının görüşleri ilişkilendirilmiş ve araştırmanın bulguları yorumlanmıştır. Özellikle kod ve temaların belirlenmesi aşamasında yabancı dil öğretimi alanında uzman bir akademisyenin görüşüne başvurulmuştur. Yine geçerliliği sağlamak adına katılımcıların görüşleri kimi yerlerde doğrudan alıntılar biçiminde aktarılmıştır. Nitel araştırma yaklaşımında geçerliğin tesis edilmesinde yaygın kullanılan yöntemlerden ikisi olan uzman görüşlerine başvurmak ve katılımcılardan doğrudan alıntılar yapmak (Sutton ve Austion, 2015; Yıldırım ve Şimşek, 2013) bu çalışmada da kullanılmıştır. Araştırmanın güvenilirliği açısından verilerin analizi iki araştırmacı tarafından bağımsız şekilde gerçekleştirilmiş ve kodlayıcıların görüşleri Miles ve Huberman'ın (1994) uzlaşma yüzdesi hesaplama formülü kullanılarak hesaplanmıştır. Kodlayıcılar arası güvenirlik katsayısının 383 görüş birliği ve 29 görüş ayrılığı üzerinden hesaplanarak \%93 olduğu bulunmuştur. Ölçüm güvenirliği formülüne göre kodlayıcılar arasındaki uyum yüzdesinin yüksekliği ölçüm güvenirliğinin de yüksek olduğunun işaretidir (Yıldırım ve Şimşek, 2013). Bu çalışmada kodlayıcılar arasında bulunan uzlaşma yüzdesine dayanılarak araştırmada yapılan kodlamanın güvenilir olduğu söylenebilir (Miles ve Huberman, 1994). Böylece uzaktan eğitim sistemiyle yürütülen Türk Dili derslerinin temel dil becerilerinin gelişimine nasıl etki ettiği, bütüncül bir biçimde analiz edilmiştir. 


\subsection{Araştırmanın etik izinleri}

Yapılan bu çalışmada "Yükseköğretim Kurumları Bilimsel Araştırma ve Yayın Etiği Yönergesi" kapsamında uyulması belirtilen tüm kurallara uyulmuştur. Yönergenin ikinci bölümü olan "Bilimsel Araştırma ve Yayın Etiğine Aykırı Eylemler" başlı̆̆ı altında belirtilen eylemlerden hiçbiri gerçekleştirilmemiştir.

Etik kurul izin bilgileri

Etik değerlendirmeyi yapan kurul adı = Adana Alparslan Türkeş Bilim ve Teknoloji Üniversitesi Bilimsel Araştırma ve Yayın Etiği Kurulu

Etik değerlendirme kararının tarihi= 04.09.2019

Etik değerlendirme belgesi sayı numarası= E.11694

\section{Bulgular}

Görüşmelerden elde edilen bulgular "Türk Öğrencilerin Görüşleri”, "Yabancı Uyruklu Öğrencilerin Görüşleri” ve "Öğretim Elemanlarının Görüşleri” başlıları altında toplanmış ve yorumlanarak sunulmuştur.

\subsection{Türk öğrencilerin görüşleri}

Türk öğrencilerin görüşleri "Dil Becerilerine Etki”, “Türk Dili Dersine İlişkin Sorunlar ve Beklentiler”, "Uzaktan Eğitime İlişkin Sorunlar ve Beklentiler" ve "Hedef Kitlenin Farklıllğından Kaynaklanan Sorunlar ve Beklentiler" kategorileri altında şekillenmiştir. Yapılan analiz sonucunda 15 kod tespit edilmiştir. Ulaşlan kodlar Tablo 3’te gösterilmektedir.

Tablo 3. Türk öğrencilerin uzaktan eğitimle yürütülen türk dili derslerine yönelik görüşleri

\begin{tabular}{ll}
\hline Temalar & Kodlar \\
\hline Dil becerilerine etki & Dört temel dil becerisinin gelişimine olumlu etkinin olmaması \\
& Dört temel dil becerisinin gelişimine olumlu etki
\end{tabular}

Türk Dili dersine ilișin sorunlar ve $\underline{\text { beklentiler }}$
Dersin içeriğine yönelik değişiklik beklentisi (geçmiş yıllardaki içeriklerin bir tekrarı gibi algılanması)

Dersin notlandırmasının kredili olmasına yönelik beklenti

Dersin varlığına ilişkin olumlu tutum

Uzaktan eğitime iliș̣in sorunlar ve $\underline{\text { beklentiler }}$
Sisteme ilişkin yönlendirme ve bilgi eksikliği

Dersin amaçlarıyla uzaktan eğitim sistemi arasındaki uyum/suzluk

Sınıfta (yüz yüze) eğitim beklentisi

Uzaktan eğitimin sınıf içi uygulama yapmaya elverişli olmaması

Uzaktan eğitimin akran öğrenmeye elverişli olmaması

Kullanılan öğretim yöntem ve tekniklerinin kısırlığı - düz anlatımın 
hâkim olması

Ders devam durumunun takibinin güçlüğü / derse devam eden öğrencilerin derste aktif olmaması

Öğrenmeye elverişli bir çevrenin olmaması

Teknik aksaklıklar

Hedef kitlenin farklılı̆̆ından kaynaklanan sorunlar ve beklentiler
Yabancı uyruklu öğrencilerin derse hazırbulunuşluğunun (Türk öğrencilere kıyasla) yeterli olmaması

Öğrencilere, uzaktan eğitimle yürütülen Türk Dili dersinin dil becerilerine nasıl etki ettiği sorulmuştur. Öğrencilerin büyük bir kısmı bu derslerin temel dil becerilerine olumlu etkisinin olmadığını söylerken bir kısım öğrenci ise temel dil becerilerinin gelişimine katkısı olduğunu ifade etmişlerdir. Bu duruma ilişkin mezun olma durumundaki İşletme Fakültesi öğrencisi TÖ1’in görüşleri aşağıdaki gibidir:

Derse biz katılamadığımız için onun [konuşma becerim] üzerinde de pek etkisi olduğunu düşünmüyorum. Yazmada belki biraz etkisi olabilir çünkü takip etmek için not almamız gerekiyor. İlk başlarda henüz derse katılıp katılmama konusunda bilincimiz yoktu. Mecburen derse katılıyorduk ve takip etme gereği duyuyorduk. Türkçe dil bilgisi ve yazım bilgisi anlamında faydası olmamıştır bence.

Öğrencilere yöneltilen sorular neticesinde Türk Dili derslerine ilişkin tespit ettikleri sorunlar, beklentiler ve çözüm önerileri alınmıştır. Bu konuda katılımcılar dersin içeriğinin ortaokul ve lisede gördükleri konularla çok benzer olduğunu ve bu açıdan düşünüldüğünde dersin müfredatının güncellenmesi gerektiğini ifade etmişlerdir. İşletme Fakültesi öğrencilerinden TÖ1’in bu konudaki görüşlerine aşağıda yer verilmiştir:

Türk Dili için bu derse ilişkin hedeflerin çok da sağlanamayacağını düşünüyorum. Çünkü biz bu dille doğuyoruz. Bu dilin içinde büyüyoruz ve üniversiteye gelene kadar da bütün eğitim yıllarımız boyunca da bu dersi almaya devam ediyoruz ve [üniversite giriş sınavında] sınavda da benim dönemimde özellikle en çok katsayısı olan derslerden bir tanesiydi, Türk Dili, Türkçe. Edebiyat da aynı şekilde. Bunu düşününce eğer biz üniversiteye gelene kadar [bilgi ve] becerilerimizi belli bir noktaya getiremediysek eğer bu eğitimlere rağmen bize sunulanlara rağmen üniversitede bir yıl içinde uzaktan eğitimle bunun [bu hedeflerin] sağlanabileceğine inanmiyorum ben.

Öğrencilerin önemli bir kısmı bu derslerin kredili olmasını istediği ve derslerden aldıkları notların ağırlıklı genel not ortalamalarına katkı yapmasını istedikleri görülmektedir. Öğrencilerin aynı zamanda Türk Dili derslerini sinıfta yüz yüze almaya yönelik bir beklentileri de bulunmaktadır. Mühendislik Fakültesi öğrencisi TÖ25’in bu konudaki görüşüne aşağıda yer verilmiştir.

Benden sonra gelecekler için bu derste bir değişiklik yapılacak olsa, bizim aldığımız dersin AKTS'si sıfirdı. Sadece "geçti" "kaldı", ortalamaya hiçbir etkisi yoktu. Bu derse bir kredi konulursa ve sınavlar bu kadar kolay olmazsa öğrenciler mecburen çalışırlar bu derslere. Çalışmaları gerekir ve krediyi düşünerek bir çaba içine girerler, ortalamamı bir nebze yükseltir mantığıyla. Bana kalırsa kredi konulmalı, AKTS'si artırılmalı. Uzaktan eğitimden ziyade biraz daha böyle birebir eğitim daha mantıklı olurdu. (TÖ25)

Uzaktan eğitim uygulamasına yönelik görüşmelerden ortaya çıkan bir diğer başlık ise öğrencilere göre uzaktan eğitimin uygulamaya ve akran öğrenmeye yeterince olanak sağlamamasıydı. İnsan ve Toplum Bilimleri Fakültesi öğrencilerinden TÖı’’un bu konudaki düşüncesine aşağıda yer verilmiştir.

Öncelikle uzaktan eğitim olduğu için bizim herkesle konuşma imkânımız yok. Direk hocanın konuşması bizim de yazarak devam etmemiz gereken bir şey. O yüzden konuşma açısından bire bir eğitim[deki katkıyı] sağlamayacaktır bu. Eğer sistemde bizim ortalamamızı etkileyecekse, gerçekten 
amaçlara [dersin amaçlarına] ulaşılmak isteniyorsa o zaman bire bir yüz yüze olabilir. Eğer gerçekten amaçlara ulaşılmak isteniyorsa uzaktan eğitim eksik bir sistem. (TÖ10)

Bütün fakülteden katılımcılar arasında yaygın olan ayrı bir kaygı kaynăg ise derse devam durumunun ve de derse etkin katılımın uzaktan eğitim sistemi üzerinden takip edilemiyor olmasıdır. TÖ 13 bu konudaki görüşünü "Genelde derse katılan sayısı dört ya da beş oluyordu. İlk haftalarda derse katılım son derece yüksekti çünkü sınıf için yeni bir dersti. Ama dersler devam ettikçe derse katılım oranı gittikçe düştü. Hatta son haftalarda baktığımda bazen bir bazen hiç kimse olmuyordu." sözleriyle ifade etmiştir.

Görüşmelerden elde edilen uzaktan eğitim sistemine ilişkin öne çlkan diğer başlıklar ise teknik aksaklıklar, dersin amaçlarıyla uzaktan eğitim sistemi arasındaki uyum/suzluk ve sisteme ilişkin yönlendirme ve bilgi eksikliğidir. Siyasal Bilgiler Fakültesi’nden TÖ17 bu konuyu "Teknik aksaklık her hafta oldu. Geçen hafta hoca tam ders anlatırken bir anda ders koptu. [Bağlantının gelmesini] yirmi dakika bekledik. Donma oluyor. Ses daha beter, sesi söylemiyorum zaten. Hocayı zor anliyoruz. Hocanın tarafında belki sıkıntı yoktur, belki tamamen sistemin kendisinde sorun vardır." sözleriyle ifade etmiştir. İşletme Fakültesi öğrencisi TÖ7 ise yaşadığı sorunları internet bağlantısı temelinde ifade etmiştir:

Teknik anlamda sorun yaşadık. Mesela bu ders bize uzaktan eğitimle olduğu için internet üzerinden almamız gerekiyordu. Internetim yoktu. Yurdun interneti yeterli olmuyordu buna girmeme. Ayrıca bilgisayardan girmek zorundayım. Telefondan da giremiyorum. Yurdun interneti yavaş, giremiyorum. Kendi internetim de olmuyor çoğu zaman. Yavaş olunca görüntü donuyor, ses de bozukluk oluyor. O zaman da hiçbir anlamı kalmıyor dersin. Bir şey anlaşılmıyor. (TÖ7)

Bir grup Türk öğrenci yabancı uyruklu arkadaşlarının derse ilişkin kendilerine kıyasla daha düşük hazırbulunuşluk düzeyinde olmalarının onların öğrenmeleri ve güdülenmeleri açısından bir haksızlı̆̆a ve de olası bir öğrenme engeline yol açabileceğini düşünmektedirler. Bu konuya ilişkin öğrenci görüşlerine aşağıda yer verilmiştir.

Ama yabancı bir öğrenci şimdi Türkçeyi fazla bilmeyen ya da yarım yamalak bilen bir öğrenci gelip de [bu dersi] alırsa yani biz lisenin başından beri hatta ilkokulun başından beri aldığımız dersler. Kendi tarihimizi kendi dilimizi öğreniyoruz. Adam [o öğrenci] için hem önemli değil hem de öğrenemez iki dönemde bence. (TÖ24)

Bana kalırsa edebiyat derslerinde sanat tarzında işlenebilir. [Türk] sanat tarihi gibi daha evrensel. Kültürle, bilgiyle doldurulabilecek bir şeyler olmalı. Sonuçta üniversiteler yabancı öğrenci de alan bir kurum. Yurt dışından gelen bir öğrencinin benim on beş yılda öğrendiğgim bir bilgiyi bir dönemde iki dönemde öğrenmesi pek mümkün değil. Yarım yamalak öğrenecek. (TÖ25)

\subsection{Yabancı uyruklu öğrencilerin görüşleri}

Yabancı uyruklu öğrencilerin görüşleri "Dil Becerilerine Etki", "Türk Dili Dersine İlişkin Sorunlar ve Beklentiler", "Uzaktan Eğitime İlişkin Sorunlar ve Beklentiler" ve "Hedef Kitlenin Farklılığından Kaynaklanan Sorunlar ve Beklentiler" kategorisi altında analiz edilmiştir. Yapılan analiz sonucunda 16 kod tespit edilmiştir. Yabancı uyruklu öğrencilerin görüşlerine ilişkin kategori ve kodlar, Tablo 4'te gösterilmektedir. 
102 / RumeliDE Journal of Language and Literature Studies 2020.S7 (October)

Evaluation of Turkish language courses in distance education: A qualitative research / Ö. Özer; Y. E. Çekici (pp. 92-110)

Tablo 4. Yabancı uyruklu öğrencilerin uzaktan öğretimle yürütülen türk dili derslerine yönelik görüşleri

\begin{tabular}{ll}
\hline Temalar & Kodlar \\
\hline Dil becerilerine etki & Dinleme, okuma ve konuşmaya kısmen olumlu etki \\
& Yazmaya olumlu etkinin olmaması
\end{tabular}

Türk Dili dersine ilișkin sorunlar ve $\underline{\text { beklentiler }}$

Uzaktan eğitime ilișkin sorunlar ve $\underline{\text { beklentiler }}$

Hedef kitlenin farklılı̆̆ından kaynaklanan sorunlar ve beklentiler
Dersin varlığına ilişkin olumlu tutum

Dersin varlığının sorgulanması

Dersin içeriği ve işleniş tarzında değişiklik beklentisi

Daha fazla uygulama yapma ihtiyacı

Devam zorunluluğu olması beklentisi

Uzaktan eğitimin uygulama yapmaya elverişli olmaması

Uzaktan eğitimin akran öğrenmeye elverişli olmaması

Uzaktan eğitimden kaynaklı ilgi ve motivasyon kaybı

Sinıfta (yüz yüze) eğitim beklentisi

Uzaktan eğitimin çalışanlara sağladığı zaman esnekliği

Yabancı uyruklu öğrencilerin derse hazırbulunuşluğunun (Türk ögrencilere kıyasla) yeterli olmaması

Türk Dili dersindeki başarısızlığın öğrencinin genel öğrenme motivasyonunu düşürme ihtimali

Düşüncelerini açıklamak için yabancı uyruklu öğrencinin beden dilini kullanma ihtiyacı

Yabancı uyruklu öğrencilere TÖMER tarzı seviyelendirilmiş dil eğitimi verilmesi

Yabancı uyruklu öğrencilere, uzaktan eğitimle yürütülen Türk Dili dersinin dil becerilerine nasıl etki ettiği sorulmuştur. Öğrencilerden bir kısmı bu derslerin dinleme, okuma ve konuşma becerilerine olumlu etki ettiğini söylerken bir kısmı olumlu etki etmediğini vurgulamıştır. Ayrıca öğrenciler bu dersin yazma becerisine olumlu etki etmediğini belirtmiştir.

Yabancı uyruklu öğrencilere, Türk Dili dersine yönelik görüşleri, bu derste yaşadıkları sorunlar ve bu derse yönelik beklentileri sorulmuştur. Bu kategori altında dersin varlığına ilişkin olumlu tutum ve dersin varlığını sorgulama olarak kodlanan iki karşıt görüş tespit edilmiştir. YÖ2, Türkiye'de çalışacağını, bu nedenle Türk Dili dersinin kendisi için yararlı olacağını ve dersin varlığını olumlu bulduğunu ifade etmiştir: "Dört yll sonra buradan bir diplomam olacak ve burada [Türkiye'de] çalışacağım. O nedenle Türkçeyi öğrenmek zorundayım. Onun için bu [ders] benim için yararlı ve oldukça iyi”. YÖ5 ise bu derste kendi bölümüyle ilgisi olmayan birçok bilginin bulunduğunu, bu nedenle bu dersin faydasız olduğunu ifade etmekte ve dersin varlığına ihtiyaç duymadığını düşünmektedir. "Türk Dilini bilmediğim için sistemi kapatıyorum. Bu nedenle faydalı olmadı. Türk Dili ve edebiyatı okusam faydalı olur ama benim için derste birçok gereksiz bilgi vardı”.

Türk Dili dersine yönelik yabancı uyruklu öğrencilerle yapılan görüşmede dersin içeriğinde yer alan dil bilgisi konularının ve derste kullanılan söz varlı̆̆ının oldukça zor olduğu yönünde görüş belirlenmiştir. 
$\mathrm{Bu}$ zorluğun aşlabilmesi için dersin yabancı uyruklu öğrenciler gözetilerek işlenmesi gerektiği ifade edilmiştir. YÖı, dersin içeriği ve işleniş tarzının değiştirilmesi gerektiğini ifade etmektedir:

[Bu ders yabancı uyruklu öğrenciler için] olsun [olmalı] ama böyle olmasın. Bu ders üzerinde etkisi edebiyat ile ilgili, müzik ile ilgili gitsin. Bu ders o yolda da gitsin. Sadece Türkçe falan bu dil ne zaman başladı falan [olmasın]. Öğrenci araştırsın mesela. Ders verdiğimiz[de] mesela çocuk okuyor, okula geliyor, ezberliyor. Bir şey aklında da kalmıyor. Türkçe geliyor, edebiyat geliyor, [Öğrenci desin] onu [o konuyu] bir araştırayım, ödev gibi. Mezun olduktan sonra hatırlayacaksın bu ödevde ne yaptım. (YÖ1)

Yabancı uyruklu öğrencilerle gerçekleştirilen görüşmede uzaktan eğitime ilişkin sorunlar ve beklentiler de belirlenmiştir. Öğrenciler uzaktan eğitimin uygulama yapmaya elverişli olmadığını, ayrıca ilgi ve motivasyonu düşürdüğünü ifade etmektedir. YÖ1, uzaktan eğitimin akran öğrenmeye ve sosyalleşmeye elverişli olmadığını belirtmekte, bu nedenle sınıfta yüz yüze dersin daha yararlı olacağını ifade etmektedir:

Bu dersi tekrar alacak olsam bu dersin yüz yüze verilmesini isterdim. Yüz yüze olduğu için [yüz yüze olduğu zaman] karşında bir hoca da olduğu için bir şey de sorabilirsin. Bir arkadaşa falan sorabilirsin. Ama evde olduğu için [zaman] yalnız yalnızlık hissedebilirsin. Tek başına kalabilirsin. Bana öyle geliyor [yüz yüze eğitimde] bir şey sorabilirsin, bir şey yazabilirsin, bir şey ifade edebilirsin. (YÖ1)

Görüşmede yabancı uyruklu öğrencilerin bu dersin sınıfta verilmesi yönündeki beklentisi ön plana çıkmakla beraber YÖ1, hem çalışan hem okuyan öğrenciler için uzaktan eğitimin zaman esnekliği sunduğunu belirtmektedir.

Araştırmada ön plana çıkan görüşlerden biri de dersin içeriğinin ve işleniş tarzının Türk öğrencilere göre tasarlanmış olması ancak yabancı uyruklu öğrencilerin farklı nitelikler taşımasıyla ilgilidir. $\mathrm{Bu}$ görüşler "Hedef Kitlenin Farklılığından Kaynaklanan Sorunlar ve Beklentiler" başlı altında çözümlenmiştir. Yabancı uyruklu öğrencilerin derse hazırbulunuşluğunun (Türk öğrencilere kıyasla) yeterli olmaması, tespit edilen başlıklardan biridir. YÖ2, İngilizce anlatılan diğer derslerde oldukça başarılı olduğunu ancak Türk Dili dersinde başarılı olamadığını belirtmektedir. Bu başarısızlık, Türk öğrencilerle yabancı uyruklu öğrenciler arasında haksız bir rekabete yol açmaktadır:

Aslında bu üniversitede iki arkadaşım var. Biri mezun oldu diğer ise hâlâ burada. Onların dil seviyesi oldukça iyi. Onlarla konuştum ve o bana dedi ki aynı şey onun da başından geçmiş. Üniversiteye geldiğinde hiç Türkçesi yokmuş. Bu [dersin] materyallerini sonraya bırakmış. Sanıyorum üçüncü yıla ya da dördüncü yıla bırakmış. Yıllar içinde Türkçesi geliştiği için aradaki farkı kapatmış. Uluslararası öğrenciler için [Türk dilini öğrenmek] oldukça zor. Sen bir Türk'sün ve kendini Çin'e gittiğini düşün ve durumumu anlarsın. Eğer dili öğrensen, o zaman [dersi] geçmek zor değil. Ama işte asıl sorun bu. (YÖ2)

YÖ5 ise dersi alan Türk ve yabancı öğrencilerin nasıl farklı önceki öğrenmelerle (prior learning) bu dersi aldıklarını aşağıdaki gibi açıklamıştır: "TÖMER'de sadece dil öğreniyorsun. Ama Türk Dili dersinde bilgi ve gramer var. Edebiyat dersi gibi. Türkler için kolay olabilir ama bizim için çok zor. Dersleri hiç dinlemedim. Sınav için verilen sorulara çalıştım ve geçtim.”

Görüşmede yabancı uyruklu öğrencilerin Türk Dili dersinde başarısız olmalarının genel öğrenme motivasyonlarını düşürdüğü sonucu da çıkmıştır. Bununla beraber Yabancı uyruklu öğrencilerin düşüncelerini açıklamak için beden dilini kullanma ihtiyacı fakat uzaktan eğitimin buna elverişli olmaması, tespit edilen sorunlardan biridir. YÖ5, söz konusu sorunların aşlabilmesi için Türk dili dersi yerine TÖMER tarzı seviyelendirilmiş dil eğitimini "Yabancı öğrenciler için TÖMER'deki gibi A1, 
A2, B1 dersleri olmalı. Konuşma, okuma, yazma, dinleme dersleri olmalı. Böyle daha faydalı olur" sözleriyle önermektedir.

Yabancı uyruklu öğrencilerin görüşleri incelendiğinde uzaktan eğitimin çeşitli aksaklıklar taşıdığı, dersin bu haliyle yabancı uyruklu öğrenciler için çok faydalı olmadığı, bu durumun Türk öğrencilerle yabancı uyruklu öğrenciler arasında haksız bir rekabete yol açtığı, Türk Dili dersindeki başarısızlığın yabancı uyruklu öğrencilerin genel öğrenme motivasyonunu düşürdüğü, bu nedenle hem ders içeriği hazırlanırken hem de ders işlenirken yabancı uyruklu öğrencilerin gözetilmesi gerektiği yorumu yapılabilir.

\section{3. Öğretim elemanlarının görüşleri}

Öğretim elemanlarının görüşleri "Dil Becerilerine Etki”, "Türk Dili Dersine İlişkin Sorunlar ve Beklentiler" ve "Uzaktan Eğitime İlişkin Sorunlar ve Beklentiler" kategorileri altında çözümlenmiştir. Yapılan analiz sonucunda 12 kod tespit edilmiştir. Öğretim elemanlarının görüşlerine ilişkin kategori ve kodlar, Tablo 5 'te gösterilmektedir.

Tablo 5. Öğretim elemanlarinin uzaktan eğitimle yürütülen türk dili derslerine yönelik görüşleri

\begin{tabular}{ll}
\hline Temalar & Kodlar \\
\hline$\underline{\text { Dil becerilerine etki }}$ & Okuma ve dinlemeye kısmen olumlu etki \\
& Konuşma ve yazmaya olumlu etkinin olmaması \\
$\underline{\text { Türk Dili dersine ilișkin sorunlar ve }}$ & Müfredat değişikliği beklentisi \\
\hline$\underline{\text { beklentiler }}$ & Dersin amaçlarıyla uzaktan eğitim sistemi arasındaki uyum/suzluk \\
& Ders saatlerinin düzenlenmesi beklentisi \\
& Derse devamın (canlı katılımın) az olması \\
& \\
\hline$\underline{\text { bzaktan eğitime ilișkin sorunlar ve }}$ & Derse devam eden öğrencilerin derste aktif olmaması \\
& Uzaktan eğitimde etkileşim olanağının sınırlı olması \\
& Uzaktan eğitimden kaynaklı ilgi ve motivasyon kaybı \\
& Uzaktan eğitimin sınıf içi uygulama yapmaya elverişli olmaması \\
& Teknik aksaklıklar \\
& Sinıfta (yüz yüze) ders beklentisi \\
\hline
\end{tabular}

Öğretim elemanlarına, uzaktan eğitimle yürütülen Türk Dili dersinin dil becerilerine nasıl etki ettiği sorulmuştur. Öğretim elemanları derse katılan öğrencilerin kendilerini dinlediğini, bu nedenle öğrencilerin dinleme becerilerinin kısmen gelişebileceğini vurgulamıştır. Öğretim elemanları uzaktan eğitim sisteminde yer alan sunuları okuyarak öğrencilerin okuma becerisinin de istenen düzeyde olmasa da gelişebileceğini ifade etmiştir. Bunla beraber uzaktan eğitimle yürütülen Türk Dili dersinin öğrencilerin yazma becerisine olumlu etki etmediğini belirtmişlerdir. ÖE3 bu derse teorik bilginin aktarıldığını ancak uygulama yapılamadığını, bu nedenle öğrencilerin yazma becerisinin gelişmediğini ifade etmektedir:

Derslerde etkileşim sağlanamıyor. Bu nedenle öğrencilere yazma etkinlikleri de yaptıramıyoruz. Öğrenciler sadece sistemdeki sohbet bölümüne yazabiliyor. Burada da yazım ve noktalama 
kurallarına dikkat etmiyorlar. Ayrıca bir kompozisyon da yazdıramıyoruz. Giriş, gelişme ve sonuç bölümlerinin nasıl yazılacağını, yazım ve noktalama kurallarını, metin türlerini anlatıyoruz ama uygulama yaptıramıyoruz. Bu nedenle derste sadece yazmaya ilişkin bilgi aktarabiliyoruz, uygulama aşamasına geçemiyoruz. Bu da öğrencilerin yazma becerisini geliştirmiyor. (ÖE3)

Öğretim elemanları, Türk Dili dersinin yazma becerisi gibi konuşma becerisine de olumlu etki etmediğini ifade etmektedir. ÖE2, özellikle uzaktan eğitim sisteminin konuşma becerisini geliştirmeye elverişli olmadığını belirtmektedir:

Uzaktan eğitim sisteminin konuşma becerisine olumsuz bir etki oluşturduğunu söyleyebilirim. Çünkü öğrencilerin özellikle kamera veya mikrofonla bize ulaşamadıkları ders sistemlerinde, bu tarz programlarda konuşma becerilerini hiç kullanmadıklarını varsayarsak ya da konuşma becerilerini bize yazı yoluyla aktarmaya çalıştıklarını varsayarsak konuşma becerisini olumsuz etkilediğini söyleyebilirim. (ÖE2)

Öğretim elemanlarıyla yapılan görüşmelerde Türk Dili dersine yönelik sorunlar ve beklentiler de belirlenmiştir. Öğretim elemanları, müfredatın günümüz koşulları ve öğrenci gereksinimlerine göre yeniden düzenlenmesi gerektiğini dile getirmektedir. ÖE1, mevcut müfredatın öğrencilerin ilgisini çekmediğini, daha önceki eğitimin bir tekrarı olduğunu ifade etmektedir. "Konular belki ilginç gelmiyor öğrencilere. Müfredata uygun konular seçiyoruz ama lisede, ortaokulda gördükleri dersler olduğu için ilginç gelmiyor onlara. Daha güncel, kendilerini daha iyi ifade edebilecekleri, daha ilgilerini çekecek konular seçilirse belki öğrencilerle daha interaktif dersler yapılabilir”.

Yapılan görüşme sonucunda dersin hedefleri ile uzaktan eğitim sistemi arasındaki uyum bakımından ise iki farklı görüş ortaya çıkmıştır. ÖE1 ve ÖE2, uzaktan eğitim sistemiyle yürütülen Türk Dili dersinin hedeflerine ulaştığını ifade ederken, ÖE3 ve ÖE4 ise bu hedeflere ulaşılmadığını ifade etmektedir. Örneğin ÖE2 "Hedefler bakımından örtüştüğünü düşünüyorum. Çünkü genel geçer ifadeler var." derken ÖE3 ise uzaktan eğitimle yürütülen Türk Dili dersinin dil becerilerini geliştiremediğini ifade etmektedir: "Uzaktan eğitimle yürütülen Türk Dili dersi, öğrencilerin dört temel dil becerisini geliştirmiyor. Öğrenci dili doğru ve güzel kullanma yeterliliği kazanamıyor. Bu bakımdan YÖK’ün belirlediği Çerçeve Program'daki hedeflerle uzaktan eğitim yoluyla yürütülen Türk Dili derslerinin uyuşmadığını düşünüyorum”. ÖE4 de dil becerilerini geliştirme hedefinin gerçekleşemediğini ifade etmektedir: "Bence [dersin amaçlarıyla uzaktan eğitim sistemi] örtüşmüyor, çünkü dili geliştirme ve kullanma konusunda öğrencilere yeterince hizmet etmiyor. Bu sebeple örtüşmüyor”. Bunların yanı sıra, ders saatlerinin, öğrencilerin aktif katılacağı bir şekilde düzenlenmesi gerektiği de ifade edilmiştir.

“Uzaktan Eğitime İlişkin Sorunlar ve Beklentiler” başlığı altında yedi kod belirlenmiştir. Öğretim elemanları, uzaktan eğitim sisteminde derse canlı katılımın çok az olduğunu, derse katılan öğrencilerin de aktif olmadığını belirtmektedir. Bununla beraber uzaktan eğitimde etkileşim olanağının sınırlı olması ve öğrencilerin motivasyonunun düşük olması da ifade edilen sorunlar arasında yer almaktadır. ÖE3 sınırlı etkileşimin hem öğretim elemanlarında hem de öğrencilerde motivasyonu düşürdüğü belirtmektedir: "Etkileşimden yoksun [uzaktan] öğretim, hoca ve öğrencide motivasyonu düşürüyor. Bu da öğrencinin başarısını düşüyor”. Uzaktan eğitimin uygulama yapmaya elverişli olmaması, tespit edilen kodlardan bir diğeridir. ÖE3, uzaktan eğitimin uygulama yapma bakımından çeşitli kısıtlar taşıdığını, bunun da özellikle konuşma becerisinin gelişimini engellediğini ifade etmektedir: "Konuşma becerisi sınıf içinde yüz yüze etkinliklerle geliştirilebilecek bir beceridir. Uzaktan eğitim sistemi buna olanak tanımıyor. Uzaktan eğitim sistemiyle öğrencilere konuşma konuları veremiyoruz, onların konuşmalarını gözlemleyemiyoruz. Sadece etkili konuşmanın kurallarını anlatabiliyoruz fakat bu da becerinin gelişmesi için yeterli olmuyor elbette”. Ayrıca öğretim elemanları, uzaktan eğitim sisteminde 
elektrik kesintisi, görüntünün donması, sesin geç gitmesi gibi teknik aksaklıkların yaşandığını da dile getirmektedir.

Söz konusu sorunlar ve dil becerilerinin daha etkili bir biçimde geliştirilebilmesi için, öğretim elemanları Türk Dili dersinin sinıfta (yüz yüze) gerçekleştirilmesi gerektiğini belirtmektedir. ÖE1, sınıfta eğitimin dinleme becerisine olumlu katkı sunduğunu deneyimlerinden yola çıkarak ifade etmektedir:

Aynı dersi yüz yüze yapsaydık dinleme becerisinin gelişimine kesinlikle etkisi olurdu diye düşünüyorum. Ben daha önce bir yll boyunca yüz yüze eğitim verdim, Türk Dili dersini vermiştim, iki öğretim döneminde. O zaman öğrencilerle etkilessimli ders yapıyorduk ve yüz yüze derslerin dinleme becerisinin gelişimine kesinlikle katkısının olduğunu düşünüyorum. (ÖE1)

Öğretim elemanlarının görüssleri incelendiğinde uzaktan eğitimle yürütülen Türk Dili derslerinin anlama becerilerine kısmen olumlu etki ettiği ancak anlatma becerilerine olumlu bir katkı sunmadığı anlaşılmaktadır. Yapılan analizde uzaktan eğitim sisteminin dil becerilerinin bütüncül bir biçimde öğretilmesine elverişli olmaması, uygulama yapmaya imkân tanımaması, sınıfta eğitiminin uzaktan eğitime göre daha yararlı olacağı yönündeki görüşler ön plana çıkmıştır. Bunun yanı sıra Türk Dili dersinin müfredatının öğrenci ihtiyaçları ve çağın koşullarına göre yeniden ele alınması görüşü de oldukça önemlidir.

\section{Tartışma, sonuç ve öneriler}

Öğretim elemanları ile Türk ve yabancı uyruklu öğrencilerin uzaktan eğitim yoluyla yürütülen Türk Dili derslerine yönelik görüşlerini tespit etmeyi amaçlayan bu çalışmada ulaşllan sonuçlar aşağıda yer almaktadır.

Türk öğrenciler, Türk Dili dersinin içeriğinin ortaokul ve lisede gördükleri konularla aynı olduğunu, bu nedenle derste sıkıldıklarını ifade etmektedir. Ayrıca Türk Dilinnin kredisiz bir ders olması da öğrencilerin motivasyonunu düşüren bir diğer etkendir. Bölüm derslerinin sinıfta, Türk Dili dersinin ise uzaktan eğitimle yürütülmesi, ayrıca Türk Dili’nin kredisiz bir ders olması, dersin “önemsiz” olarak algılanmasına yol açmaktadır. Bu da öğrenme-öğretme süreçlerini olumsuz anlamda etkilemektedir. Uzaktan eğitim yoluyla işlenen derslerde düz anlatım tekniğinin çok yoğun kullanılması, yeterince uygulama yapılmaması, bu sistemin akran öğrenmeye elverişli olmaması, teknik aksaklıklar, öğrencilerin aktardığı sorunlar arasında yer almaktadır. Öğrenciler ayrıca dersi almadan önce ve dersin ilk zamanlarında kendilerine yeterince bilgilendirme yapılmadığından dert yanmışlardır. $\mathrm{Bu}$ dersi alan öğrencilerin birinci sınıf öğrencileri ve üniversitedeki işleyişe ve sisteme de yabancı oldukları düşünüldüğünde bunun oldukça anlaşllabilir bir durum olduğu görülmektedir. Yaman (2015) ortak zorunlu İngilizce dersleri üzerine yürüttüğü çalışmasında benzer bir bulguya ulaşmış ve uzaktan eğitim sistemiyle ilgili öğrencilere gerekli yönlendirmenin sağlanması gereğinin altını çizmiştir. Bu sorunlar nedeniyle öğrenciler, sınıfta (yüz yüze) eğitim beklentisini dile getirmektedir. Ayrıca Türk öğrencilerin, yabancı uyruklu öğrencilerin derse hazırbulunuşluğunun (Türk öğrencilere kıyasla) yeterli olmadığını ifade etmeleri de oldukça anlamlıdır.

Yabancı uyruklu öğrenciler, hazırbulunuşluklarının bu dersi almak için yeterli olmadığını, bu durumun başarısızlığa, başarısızlığın da genel öğrenme motivasyonlarının düşmesine yol açtığını ifade etmektedir. Ayrıca Türk öğrencilerin bu derste daha avantajlı olduğunu, bu durumun haksız rekabete sebep olduğunu düşünmektedirler. Yabancı uyruklu öğrenciler, uzaktan eğitimin uygulama yapmaya elverişli olmadığını ifade etmekte, daha yararlı olabilmesi için dersin yüz yüze (sınıfta) 
gerçekleştirilmesi önerisini vurgulamaktadırlar. Öğrencilerin önemini vurguladıkları beden dili ve akran öğrenme ihtiyacı, öğrencilerin devamsızlıklarının ya da olası başarısızlıklarının altında yatan nedenlerden biri olabilir. Gürer, Tekinarslan ve Yavuzalp (2016) de uzaktan eğitim hakkındaki öğretim elemanı görüşleri üzerine yaptıkları çalışmada bire bir etkili iletişi kuramama, öğrencinin sınıf içindeki bireysel durumlarını gözlemleyememe, göz teması kuramama, öğrencilerin sanal sınıfta utangaç davranabilmeleri ve öğretim elemanları ile öğrenciler arasındaki iletişim kopukluğu gibi sorunlar rapor etmişlerdir. Yabancı uyruklu öğrenciler, ders içeriği ve dersin işleniş yöntemi belirlenirken yabancı uyruklu öğrencilerin de gözetilmesi gerektiğini ön plana çıarmaktadırlar. Dersin yazma becerisinin gelişimine olumlu etkisinin olmadığını da ifade etmektedirler.

Öğretim elemanları, uzaktan eğitimin etkileşime ve uygulamaya imkân tanımadığını belirtmektedir. Özellikle yazılı anlatımın gelişmesi açısından sınıf içi uygulamaların önemi Kan ve Fidan'ın (2016) üniversite öğrencileri üzerine yürütmüş olduğu çalışmada da ifade edilmiştir. Uzaktan eğitimin kısıtlılığı nedeniyle derslerde ağırlıklı olarak teorik bilginin aktarıldığını, dil becerilerini geliştirmeye yönelik etkinliklerin yetersiz kaldığını ifade etmektedirler. Bu kapsamda öğretim elemanları, dersin bu haliyle konuşma ve yazma becerisinin gelişimine olumlu etkisinin olmadığını düşünmektedir. Uzaktan eğitimde öğrencilerin derse düzenli bir biçimde devam etmediğini, derse devam eden öğrencilerin de aktif bir biçimde katılım sağlamadığını belirtmektedirler. Öğretim elemanlarının görüşmelerde altını çizdikleri bir diğer konu ise derslerde öğrencilerin yaşadıkları ilgi ve motivasyon kaybı olmuştur. Bu konuda Güneş ve Güneş (2016) Bilgisayar Programcllğı ve İş Sağllğı ve Güvenliği programlarındaki öğrencilerle yürüttükleri çalışmada uzaktan eğitim yoluyla yapılan derslerin gün ve saatlerinin öğrencilerin ilgi ve motivasyonlarını artıracak şekilde ayarlanması gereğini belirtmişlerdir. Benzer bir şekilde Simons, Beaumont ve Holland (2018) uzaktan eğitim yoluyla ders alan öğrencilerin öz-disiplin, bağımsız çalışma ve motivasyon düşüklüğü gibi sorunlar yaşayabileceklerini belirtmişlerdir. Öğretim elemanları, Türk Dili dersi açısından sınıfta eğitiminin uzaktan eğitime göre daha yararlı olacağı yönünde görüş bildirmektedir. Bunun yanı sıra dersin müfredatının öğrenci ihtiyaçları ve çağın koşullarına göre yeniden ele alınması gerektiği görüşünü de dile getirmektedir

$\mathrm{Bu}$ araştırmada, uzaktan eğitimle yürütülen Türk Dili derslerinin verimlilik ve etkililik bakımından kimi sınırlılıklar taşıdığı görülmektedir. Bu sınırılıkların bir bölümü uzaktan eğitim sisteminden, bir bölümü Türk Dili dersinin içeriğinden, bir bölümü de ders işleniş sürecinde yabancı uyruklu öğrencilerin gözetilmemesinden kaynaklanmaktadır. Bu sorunların çözülebilmesi için öncelikle ders içeriğinin güncellenmesi gerektiği söylenebilir. Gülay ve Ungan’ın (2015) çalışmasında uzaktan eğitim yoluyla yürütülen derslere öğrenci görüşleri toplanmıştır ve öğrencilerin bu dersin içeriğinin geçmişte öğrendikleri konuların bir tekrarı olarak düşündükleri ortaya çıkmıştır. Türk Dili dersinin içeriği, çağın koşulları, öğrenci ihtiyaçları ve yabancı uyruklu öğrencilerin hazırbulunuşluğu gözetilerek yeniden ele alınmalıdır. Gülay ve Ungan (2015) da ortak zorunlu Türk Dili dersleriyle ilgili benzer bir bulguya ulaşmışlar ve öğrencilerin yllardır benzer içerikleri görüyor olmaktan kaynaklanan bıkkınlık sonucunda derse yönelik ilgisiz davrandıklarını ifade etmişlerdir. Bu nedenle dersin günümüzün koşullarına göre amaçlar ve içerik açılarından güncellenmesi ihtiyacı belirgin olmakla beraber bunun öncesinde geniş kapsamlı bir ihtiyaç analizi yapılması gereklidir.

Uzaktan eğitimle yürütülen Türk Dili derslerinin anlatma becerilerine (konuşma ve yazma) katkı sunmadığı yönünde görüş birliği vardır. Bu kapsamda dersin yüz yüze gerçekleştirilmesi, öğrencilerin dili etkili kullanabilmeleri açısından daha yararlı olacaktır. Dersin yüz yüze gerçekleştirilemediği durumlarda ise dil becerilerini geliştirmek için daha fazla uygulama yapma imkânı oluşturulmalıdır. Aynı zamanda öğretim yönteminin çoklu ortam materyalleri ile desteklenmesi ve öğretim 
elemanlarının öğrencilere randevular vermek yoluyla bir araya gelmeleri ve yaşadıkları teknik ya da öğrenme sorunlarını irdelemeleri önemli görülmektedir. Yabancı uyruklu öğrencilerin dersi geçmelerini, Türkiye'de bulunmaları neticesinde yllar içinde Türkçelerinin gelişeceği beklentisine bağlamaları yanlış olmakla beraber bir o kadar büyük bir sorumluluğu da dersi veren öğretim elemanlarına yüklemektedir. Bu öğrencilere ders dışı kapsamlı bir rehberlik yapılması gereği olabilir.

Ayrıca uzaktan eğitimle yürütülen Türk Dili derslerinde öğrencilerin motivasyonunun düşük olduğu anlaşılmaktadır. Bunun için öğretim elemanlarının farklı yöntemlerle dersi ilgi çekici kılmaları gerekmektedir. Bunu sağlamada atılabilecek adımlardan biri de Gürer, Tekinarslan ve Yavuzalp’in (2016) dile getirdiği öğretim elemanlarına yönelik eğitimdir. Bu eğitimin uygulama temelli olması önem arz etmektedir. Öğrencilerin uzaktan eğitimle verilen Türk Dili derslerine karşı motivasyonlarının artması için öğretim elemanların atacağı adımlar önemli olmakla beraber öğrencilerin teknik sorun yaşadıkları zaman izlemeleri gereken adımların net olması da önemlidir. Bu anlamda teknik bir yetkilinin belirlenmesi ve öğrencilere de teknik sorun yaşadıkları zaman bu kişiyle ne yolla iletişime geçecekleri konusunda bilgilendirme yapılması gerekmektedir. Potter'ın (2013) ifade ettiği gibi uzaktan eğitim sistemi ile ilk defa ders alacak üniversite öğrencilerine yönelik teknik destek birimi bulunması, platformun kullanımına yönelik oryantasyon yapılması ve çevrim içi kaynaklara ulaşım gibi konularda yardım kılavuzunun sağlanması etkili bir öğrenme için gereklidir.

\section{Kaynakça}

Akkaya, N., \& Sevindi, Z. E. (2015). Üniversitelerde okutulan ortak zorunlu Türk dili derslerine yönelik tutum ölçeği geliştirme. Buca Eğitim Fakültesi Dergisi, 39, 92-103. Erişim adresi http://dergipark.org.tr/deubefd/issue/25110/265104

Arslan, A. (2018). Türk dili dersinin uzaktan eğitimle verilmesine ilişkin öğretim elemanı ve öğrenci görüşlerinin değerlendirilmesi (Ağrı İbrahim Çeçen Üniversitesi örneklemi). Uluslararası Kültür ve Bilim Kongresi 3-4-5 Mayıs 2018 Tam Metin Kitabı, 577-582.

Bircan, H. (2018). Cumhuriyet Üniversitesi öğrencilerinin uzaktan eğitimde sunulan derslere yönelik bakış açısı. Avrasya Sosyal ve Ekonomi Araştırmaları Dergisi, 5(12), 91-100. Erişim adresi http://dergipark.org.tr/asead/issue/41905/505237

Bozkurt, A. (2017). Türkiye'de uzaktan eğitimin dünü, bugünü ve yarını. Açıöğretim Uygulamaları ve $\begin{array}{llll}\text { Araştırmalar } \quad \text { Dergisi, } & 3(2), & 85-124 . & \text { Erişim }\end{array}$ http://dergipark.org.tr/auad/issue/34117/378446

Cabı, E., \& Ersoy, H. (2017). Yükseköğretimde uzaktan eğitim uygulamalarının incelenmesi: Türkiye örneği. Yükseköğretim ve Bilim Dergisi, 7(3), 419-429. http://doi.org/10.5961/jhes.2017.219

Cemiloğlu, M. (2004). Üniversitelerde okutulan Türk dili dersi ile ilgili tespitler değerlendirmeler ve öneriler. Uludă̆ Üniversitesi Eğitim Fakültesi Dergisi, 17(2), 173-182. Erişim adresi: http://dergipark.org.tr/uefad/issue/16680/173318

Croft, N., Dalton, A., \& Grant, M. (2010). Overcoming isolation in distance learning: Building a learning community through time and space. Journal for Education in the Built Environment, 5(1), 27-64. https://doi.org/10.11120/jebe.2010.05010027

Çakmak, A. Ç. (2013). Uzaktan eğitim hizmetinin öğrenciler tarafından değerlendirilmesi. Karabük Üniversitesi’nde bir uygulama. İstanbul Ticaret Üniversitesi Sosyal Bilimleri Dergisi, 12(23), 263-287.

Çakır, Ö., Calp, M. H., \& Doğan, A. (2015). Uzaktan eğitimde içerik geliştirme süreci: Gazi Üniversitesi Bilişim Enstitüsü örneği. Cumhuriyet International Journal of Education, 4(1), 1-20.

Çotuksöken, Y. (2014). Uygulamalı Türk Dili. İstanbul: Papatya Yayınları. 
Efe, I., \& Ozer, O. (2015). A corpus-based discourse analysis of the vision and mission statements of universities in Turkey. Higher Education Research \& Development, 34(6), 1110-1122. http://dx.doi.org/10.1080/07294360.2015.1070127

Fraenkel, J. R., Wallen, N. E., \& Hyun, H. H. (2012). How to design and evaluate research in education (8th edition). New York: McGraw Hill

Gregory, M. S-J., \& Lodge, J. M. (2015). Academic workload: The silent barrier to the implementation of technology-enhanced learning strategies in higher education. Distance Education, 36(2), 210230. https://doi.org/10.1080/01587919.2015.1055056

Gülay, E., \& Ungan, S. (2015). Türk dili dersinde içerik ve sınıf ortamının dersin etkililiği açısından incelenmesine yönelik aksiyon araştırması. International Journal of Language Academy, 3(1), 337-360.

Güneş, A., \& Güneş, G. (2016). Uzaktan eğitim dersini ortak alan örgün ve uzaktan eğitim öğrencilerinin başarılarının karşılaştırılması. Eğitim ve Öğretim Araştırmaları Dergisi, 5(2), 43-47.

Gürer, M. D., Tekinarslan, T., \& Yavuzalp, N. (2016). Çevrimiçi ders veren öğretim elemanlarının uzaktan eğitim hakkındaki görüşleri. Turkish Online Journal of Qualitative Inquiry, 7(1), 47-78. https://doi.org/10.17569/tojqi.74876

Kan, A. Ü., \& Fidan, E. K. (2016). Türk dili dersinin uzaktan eğitimle yürütülmesine ilişkin öğrenci algıları. Turkish Journal of Educational Studies, 3(2), 23-45. Erişim adresi http://turkjes.firat.edu.tr/index.php/turk-jes/article/view/168/150

Karataş, M. (2013). Üniversitelerdeki Türk dili dersi ve Türkçe konusundaki tutumlar. Turkish Studies, 8(1), 1881-1898. http://dx.doi.org/10.7827/TurkishStudies.4297

Kavcar, C., Oğuzkan, F., \& Sever, S. (1999). Türkçe öğretimi. Ankara: Engin Yayınları.

Kethüda, Ö. (2015). Türkiye'deki uluslararası öğrenci hareketliliği üzerine bir araştırma. Yükseköğretim Dergisi, 5(3), 147-161. http://doi.org/10.2399/yod.15.015

Kılınç, M. (2015). Uzaktan eğitim uygulamalarının etkililiği üzerine bir araştırma "İnönü Üniversitesi uzaktan eğitim merkezi ilahiyat lisans tamamlama programı örneği”" (Yayımlanmamış doktora tezi). İnönü Üniversitesi, Malatya, Türkiye.

Kurbaş, A. (2017). Attitudes of students taking Turkish language and literature lesson through distance education program in higher education (Gümüşhane University sample). International Journal of Language Academy, 5(8), 449-457. http://dx.doi.org/10.18033/ijla.3850

Miles, M. B., \& Huberman, A. M. (1994). Qualitative data analysis: An expanded sourcebook (2. baskı). Sage Publications, Inc.

Nage-Sibande, B., \& Morolong, B. L. (2018). A trend analysis of opportunities and challenges of open and distance learning provision in dual-mode institutions. Distance Education, 39(4), 495-510. https://doi.org/10.1080/01587919.2018.1457951

Özdemir, E. (1983). Anadili öğretimi. Türk Dili Dil ve Edebiyat Dergisi, 379-380, 18-30.

Potter, J. (2013). Beyond access: Student perspectives on support service needs in distance learning. Canadian Journal of University Continuing Education, 24(1), 59-82. https://doi.org/10.21225/D5R88Q

Ritchie, J., \& Lewis, J. (2003). Qualitative research practice: A guide for social science students and researchers. London: SAGE Publications.

Sarıtunç, B. (2016). Yükseköğretimde Türk dili derslerinin öğrencilerin duyuşsal gelişimine katkısı. Karaelmas Journal of Educational Sciences, 4(1), 50-58. Erişim adresi http://ebd.beun.edu.tr/index.php/KEBD/article/view/77/113

Simons, J., Beaumont, K., \& Holland, L. (2018). What factors promote student resilience on a level 1 distance learning module? Open Learning, 33(1), 4-17. https://doi.org/10.1080/02680513.2017.1415140 
Subic, A., \& Maconachie, D. (2004). Flexible learning technologies and distance education: A teaching and learning perspective. European Journal of Engineering Education, 29(1), 27-40. https://doi.org/10.1080/0304379032000129322

Sutton, J., \& Austin, Z. (2015). Qualitative research: Data collection, analysis, and management. CJHP, 68(3), 226-231. http://doi.org/10.4212/cjhp.v68i3.1456

Şahin, M., \& Demirtaş, H. (2014). Üniversitelerde yabancı uyruklu öğrencilerin akademik başarı düzeyleri, yaşadıkları sorunlar ve çözüm önerileri. Milli Eğitim Dergisi, 44(204), 88-113. Erişim adresi http://dergipark.org.tr/milliegitim/issue/36160/406467

Tulunay Ateş, Ö. (2014). Yükseköğretimde uzaktan eğitimin sayısal verilerle değerlendirilmesi. Bayburt Üniversitesi Eğitim Fakültesi Dergisi, 9(1), 22-40. Erişim adresi http://dergipark.org.tr/befdergi/issue/23139/247166

Vural, H. (2007). Üniversitelerde okutulan Türk dili dersi üzerine. TDK Yayınları Türk Dili Dergisi, 669, 496-503. Erişim adresi http://turkdili.gen.tr/files/hvura_uniokutulanturkdilidersuzerine.pdf

Yaman, İ. (2015). Üniversitelerde zorunlu İngilizce (51) derslerinin uzaktan eğitim yoluyla verilmesinin artı ve eksileri. Turkish Studies, 1O(7), 967-984. http://dx.doi.org/10.7827/TurkishStudies.8108

Ylldırım, A. ve Şimşek, H. (2013). Sosyal bilimlerde nitel araştırma yöntemleri. Ankara: Seçkin.

Yükseköğretim Kanunu (1981). T. C. Resmi Gazete, 2547, 4 Aralık 1981.

Yükseköğretim Kurulu (YÖK) (2018). Yükseköğretim kurumlarında uzaktan öğretime ilişkin usul ve esaslar. Erişim Adresi

https://www.yok.gov.tr/Documents/Kurumsal/egitim_ogretim_dairesi/Uzaktan_ogretim/yuk sekogretim_kurumlarinda_uzaktan_ogretime_iliskin_usul_ve_esaslar.pdf 